\title{
A Case of Direct Peroral Cholangioscopy-Guided Intraductal Radiofrequency Ablation for Malignancy Biliary Obstruction via Choledochoduodenostomy Orifice
}

\author{
Jin Suk Kang, Dong-Uk Kim, Jeong Eun Lee, Min Ji Kim, Geun Am Song, Jeong Heo, Dong Hoon Baek, Tae Wook Kim \\ Department of Internal Medicine, Pusan National University School of Medicine, Busan, Korea
}

BAlthough intraductal radiofrequency ablation (RFA) has been reported to be a feasible treatment of malignancy biliary obstruction in unresectable cholangiocarcinoma, endoscopic retrograde cholangiopancreatography (ERCP)guided intraductal RFA has a disadvantage that cannot be directly visualize the biliary tract using the fluoroscopic image. On the other hand, direct peroral cholangioscopyguided intraductal RFA is easy to insert catheter and apply treatment by visualizing the bile duct lesions. We present a case of direct peroral cholangioscopyguided intraductal RFA without biliary stent in 67-year-old woman patient with cholangiocarcinoma for treatment of malignancy biliary obstruction. In the past, she underwent choledochoduodenostomy for intrahepatic stones. She underwent direct peroral cholangioscopy-guided intraductal RFA via choledochoduodenostomy orifice, and biliary patency was preserved for 90days without additional treatment such as biliary stent and severe complication. Direct peroral cholangioscopy-guided intraductal RFA is expected to be able to reduce the complications of the procedure by ensuring the bile duct lesions. Prospective studies with long term follow up are warranted.

Korean J Pancreatobiliary 2015;20(3):140-145

Keywords: Cholangiocarcinoma, Intraductal radiofrequency ablation, Direct peroral cholangioscopy

\author{
Received May. 14, 2015 \\ Revised Jun. 14, 2015 \\ Accepted Jun. 23, 2015
}

Corresponding author: Tae Wook Kim

Department of Internal Medicine, Pusan National University Hospital, 179 Gudeok-ro, Seo-gu, Busan 602-739, Korea

Tel. +82-51-240-7225 Fax. +82-51-244-8180

E-mail; taewook80@hanmail.net

This is an Open Access article distributed under the terms of the Creative Commons Attribution Non-Commercial License (http:// creativecommons.org/licenses/by-nc/3.0/) which permits unrestricted non-commercial use, distribution, and reproduction in any medium, provided the original work is properly cited.

Copyright $(2015$ by The Korean Journal of Pancreas and Biliary Tract
서 론

담관암(cholangiocarcinoma)은 진단 시 10-20\%에서 수술 이 가능하고, ${ }^{1}$ 수술이 불가능한 담관암은 1 년 생존율이 $20 \%$ 정도로 예후가 매우 불량하다. ${ }^{2}$ 수술이 불가능한 담관암은
$50 \%$ 이상에서 악성 폐쇄성 황달이 발생하며, 담즙 울혈로 인한 담관염 및 패혈증으로 대부분 사망에 이르게 된다. 내 시경 혹은 경피적인 접근 방법을 통해서 담즙 울혈을 호전시 키는 것이 예후와 생존 기간을 향상시킬 수 있기 때문에, 고 식적 치료는 담관의 개존을 유지하는 것에 초점을 맞추고 있 
다. ${ }^{3}$ 담관 내 스텐트를 유치하는 방법은 담관의 개존을 유지 하기 위한 대표적인 치료로 많이 사용하고 있으나, ${ }^{4,5}$ 담관암 의 진행 혹은 스텐트 내 찌꺼기로 인해서 스텐트 폐쇄가 발 생하여 이후 추가적인 시술이 필요한 문제점이 있다. 따라서 스텐트 개존 기간의 연장을 위하여 자가 팽창형 금속 스텐트 (self expandable metal stent), 항암화학요법(chemotherapy), 광역동치료(photodynamic therapy) ${ }^{6}$ 등이 단독 또는 병 합하여 시행되고 있다.

최근, 담관 내 고주파 열치료(intraductal RFA)의 안정성 과 효율성에 관한 연구와 함께 스텐트의 개존 기간을 늘리기 위한 연구가 진행되고 있다. ${ }^{2,7}$ 한 연구에서는 담관 내 고주파 열치료를 스텐트의 삽입과 동시에 적용하였을 경우, 스텐트 단독으로 적용한 군과 비교하여서 생존 기간의 차이는 없었 으나, 고주파 열치료가 담관암 환자의 평균 생존 기간을 연 장시키는 것으로 보고하였으며, ${ }^{3}$ 다른 연구결과에서는 스텐 트의 삽입과 동시에 담관 내 고주파 열치료를 적용하였을 때, 금속 스텐트의 개존 기간이 218 일, 플라스틱 스텐트의 개 존 기간이 115 일로 기존에 보고되었던 스텐트 개존 기간보 다 우월한 것으로 보고하였다. ${ }^{8}$ 내시경적 접근을 통한 담관 내 고주파 열치료와 광역동치료의 효과를 비교한 연구에서 는, 두 치료간 생존율의 통계적 차이는 없는 것으로 보고하 였다(중앙생존율 9.6개월 vs. 7.5개월, $p=0.799$ ). ${ }^{9}$ 이를 통해 담관 내 고주파 열치료는 광역동치료와 더불어 국소적인 종 양억제를 통해서 환자의 평균 생존율 향상이 기대되는 치료 로 받아들여지고 있다. ${ }^{2}$ 현재 주로 사용되고 있는 담관 내 고 주파 열치료는 직접 병변을 확인 후 적용하는 것이 아니라,
투시조영에 확인되는 협착부위에 열을 적용하게 되므로 병 변의 위치를 정확히 확인하기 힘든 제한점이 있다. 하지만 직접 경구 담관 내시경(direct peroral cholangioscopy)은 세 경 위장관내시경(slim gastroscope)을 이용하여서 우수한 이 미지를 제공하며, 직접 담관을 보면서 치료적 시술을 시행할 수 있다. ${ }^{10}$

저자들은 총담관십이지장문합술(choledochoduodenostomy)을 시행 받은 환자에서 직접 경구 담관 내시경을 통하 여 담관의 병변부를 직접 관찰하면서 담관 내 고주파 열치료 를 시행한 증례를 문헌 고찰과 함께 보고하는 바이다.

\section{증 례}

67 세 여자 환자가 1 주간 심해진 황달과 전신 쇠약감을 주 소로 응급실에 내원하였다. 30 년 전 간내 담관 결석 및 담낭 결석으로 간 좌외측과 후측 구역절제술(left lateral and posterior hepatic segmentectomy), 총담관십이지장문합술과 담 낭절제술(cholecystectomy)을 시행 받았다. 10년 전 담관경 화증(biliary cirrhosis)을 진단받았고 이후 외래 추적 관찰을 하였다. 18 개월 전 황달 및 오한을 주소로 입원하여, Bismuth 4형의 간문부 담관암(stage I, T1N0M0)을 진단받았다 (Fig. 1A). 간이식을 포함한 수술적 치료는 환자가 거부하여 담관의 협착부위에 대하여 광역동치료와 함께 Gemcitabine 과 Cisplatin으로 9주기의 항암화학요법을 시행하였다. 다른 추가적인 치료없이 담관의 개존이 유지되고 안정 병변을 보 여 외래에서 경과 관찰하였다.
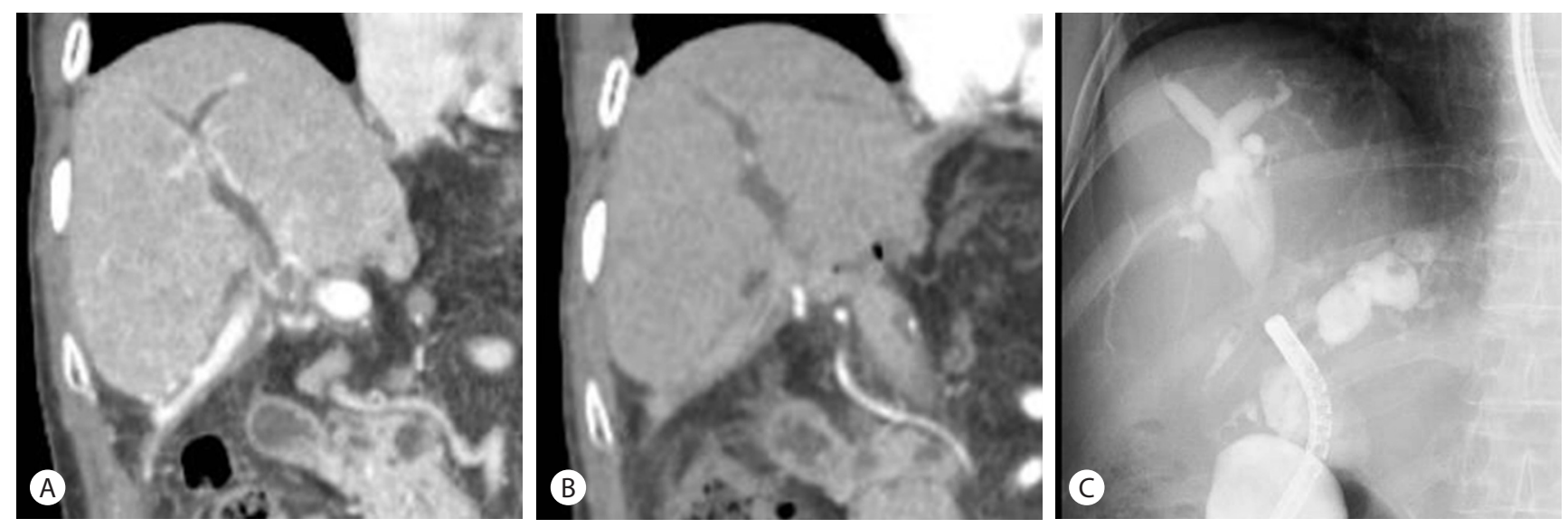

Fig. 1. (A) Abdominal computed tomography scan shows soft tissue density at hepatic hilum with mild dilatation of the intrahepatic bile duct at the time of diagnosis. (B) Abdominal computed tomography scan shows stricture at hepatic hilum and dilatation of the intrahepatic bile duct at the time of admission. (C) Fluoroscopic finding before intraductal radiofrequency ablation shows obstructed common hepatic duct and both intrahepatic bile duct. 
내원 당시 의식은 명료하나 만성 병색을 보였으며, 활력증 후는 정상이었다. 공막에 황달이 관찰되었고 복부의 압통이 나 반발통은 없었다. 혈액검사로는 혈색소 $7.7 \mathrm{~g} / \mathrm{dl}$, 백혈구 $3,210 / \mathrm{mm}^{3}$, 혈소판 $50,000 / \mathrm{mm}^{3}$, AST/ALT 33/18 IU/L, ALP $157 \mathrm{IU} / \mathrm{L}$ r-GT $69 \mathrm{IU} / \mathrm{L}$, total bilirubin $6.17 \mathrm{mg} / \mathrm{dL}$, direct bilirubin $4.38 \mathrm{mg} / \mathrm{dL}$, amylase/lipase 90.0/57.7 U/L, CA 19-9 56.38 U/mL, CRP $4.34 \mathrm{mg} / \mathrm{dL}$ 이었다. 복부 컴퓨터 단 층 촬영(Computed tomography)에서는 총간관과 간문부의 종괴 및 협착소견이 관찰되었으며 근위부 간내 담관의 확장 과 담관 기종이 관찰되었다(Fig. 1B).

진행성 병변에 대하여 광역동치료와 항암화학요법을 다시 시행하려 하였으나 환자가 거부하여 직접 경구 담관 내시경 하 담관 내 고주파 열치료를 시행하였다. 사용한 세경 내시 경으로는 GIF-XP260 (Olympus Co., Tokyo, Japan)을 사용 하였으며 유도철선 등 보조기구의 사용 없이 총담관-십이지 장 문합부위를 통해 총간관으로 내시경을 진입하였다. 총간 관으로 내시경 진입 시 간관의 내강을 둘러싼 결절성 종괴와 이로 인한 간관의 폐쇄가 관찰되었다. 투시조영에서 간문부 간관과 좌측과 우측 간내 간관의 폐쇄가 확인되었다(Fig. $1 \mathrm{C})$. 내시경 유도 하에 협착부의 근위부로 유도철선을 진입 시키고 고주파 열치료 프로브를 간문부 간관과 우측 간내 간 관에 걸친 폐쇄부위에 고정 후 담관 내 고주파 열치료를 시 행하였다. 열치료는 직접 경구 담관 내시경으로 병변을 확인
하면서 진행하였으며, 고주파 열치료 프로브는 직경 $7.5 \mathrm{Fr}$, 길이 $2.2 \mathrm{~cm}$ 의 ELRA 전극카테터(STARmed, Goyang, Ko$\mathrm{rea}$ 를 이용하여, $10 \mathrm{~W}$ 의 전력이 120 초 동안 공급되도록 하 였고, 담관 내 온도가 $80^{\circ} \mathrm{C}$ 이상이 되면 전력공급이 중단되 고 $75^{\circ} \mathrm{C}$ 이하가 되면 다시 전력공급이 되도록 시행하였다 (Fig. 2). 시술 후 투시조영에서 간문부 간관과 우측 간내 간 관의 교통이 확인되었으며 스텐트 이탈 가능성 있어 플라스 틱이나 금속 스텐트 등은 거치하지 않았다. 환자는 시술 후 당일 38도의 열이 한 차례 있었으나 이후 추가적인 발열은 없었다. 입원 4 일째 직접 경구 담관 내시경을 재시행 하였고 출혈 및 천공 등의 시술 합병증은 확인되지 않았다. 입원 7일 째 같은 방법으로 직접 경구 담관 내시경하 담관 내 고주파 열치료를 재시행하였다. 직접 경구 담관 내시경으로 좌측 간 내 간관의 폐쇄를 확인하고 폐쇄부위로 카테터 진입 후 조영 제를 투여하였다. 폐쇄부위를 방사선 투시상으로 확인하고 $7.5 \mathrm{Fr}$, 길이 $1.8 \mathrm{~cm}$ 의 전극카테터를 좌측 간내 간관의 폐쇄 부위에 고정 후 $10 \mathrm{~W}$ 의 전력을 120 초 동안 공급하여 담관 내 온도가 $75-80{ }^{\circ} \mathrm{C}$ 로 유지되도록 고주파 열치료를 시행하였다. 입원 10 일째 직접 경구 담관 내시경하 담관 조영술을 재시행 하였고 출혈 및 천공 등의 합병증은 확인되지 않았다. 간내 간관 주위로 괴사조직이 관찰되어 생리식염수로 세척하여 제거하였고 간내 간관의 개존은 유지되었다(Fig. 3). 입원 기 간 중 Cefotaxime과 Metronidazole의 병합요법으로 광범위
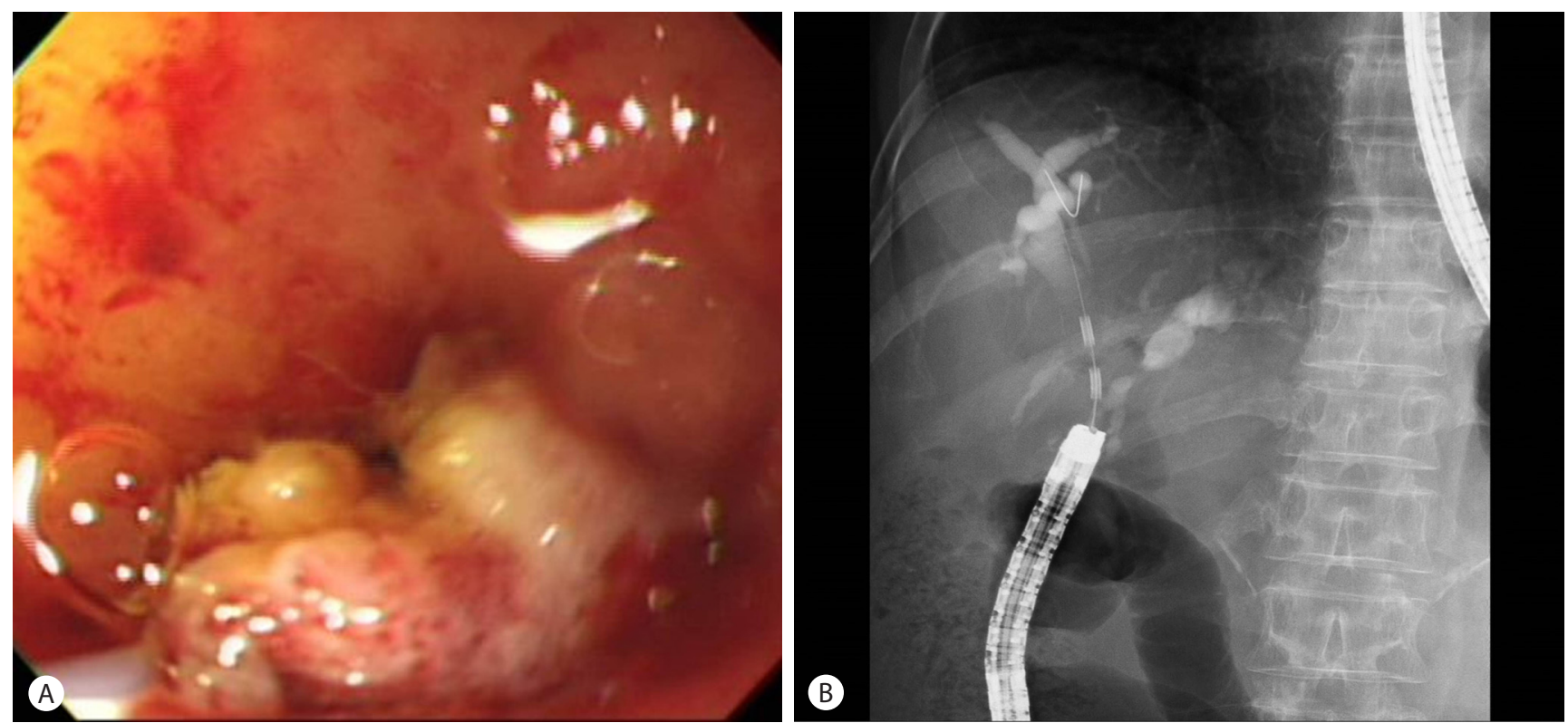

Fig. 2. Direct peroral cholangioscopy-guided intraductal radiofrequency ablation was performed through choledochoduodenostomy orifice in a 67-year-old woman with cholangiocarcinoma (Bismuth type IV). (A) Cholangioscopic view shows obstructed common hepatic duct for cholangiocarcinoma. (B) Fluoroscopic findings shows inserted the RFA catheter at right hepatic duct. 


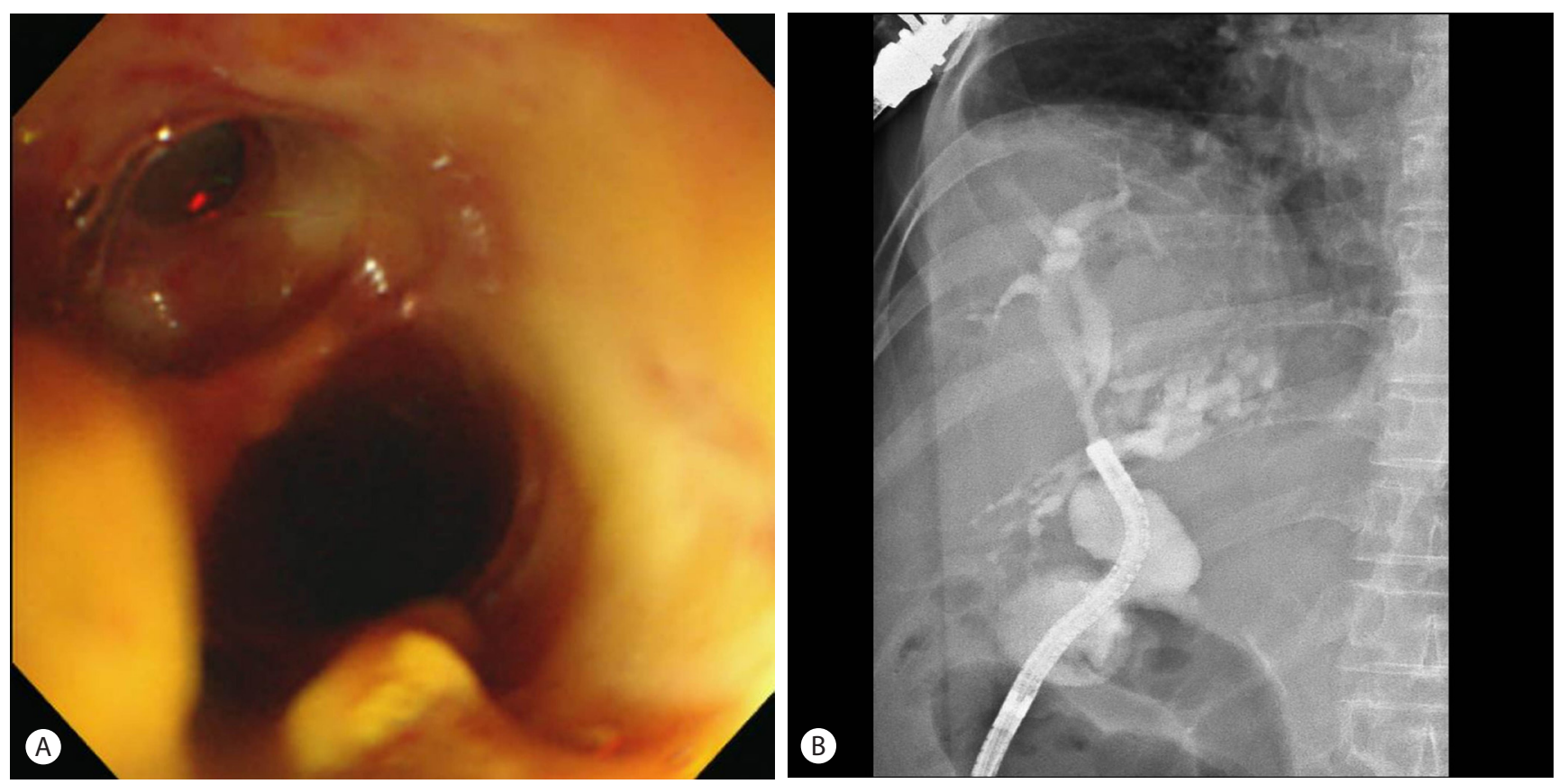

Fig. 3. After direct peroral cholangioscopy-guided intraductal radiofrequency ablation, follow up direct peroral cholangioscopy with fluoroscopy was performed. (A) In cholangioscopic view, there was no complications perforation and bleeding. (B) Fluoroscopic finding shows the biliary patency is preserved.

항생제를 정맥 주사하였으며 시술 후 담관염 및 패혈증, 출 혈, 담관 천공 등의 합병증은 발생하지 않았다. 입원 11 일째 시행한 혈액검사상 total bilirubin과 direct bilirubin은 2.61 $\mathrm{mg} / \mathrm{dL}$ 와 $1.92 \mathrm{mg} / \mathrm{dL}$ 로 감소하였으며 전신 쇠약감은 호전되 었다. 입원 12 일째 환자는 퇴원하였다.

퇴원 후 본원 소화기 내과 외래를 통해 추적관찰 하였다. 5 회의 외래 방문 시 시술에 대한 합병증은 관찰되지 않았으며 담관 폐쇄의 증거는 관찰되지 않았다. 환자는 퇴원 후 3 개월 뒤 복통 및 복부팽만감으로 본원 응급실에 재입원하였으며, 간경화로 인한 복수와 급성신부전으로 진단 받았다. 입원 당 일 응급실에서 시행한 복부 컴퓨터 단층 촬영상 다량의 복수 가 확인 되었으나 담관의 폐쇄소견은 관찰되지 않았다. 환자 는 간기능 악화 및 간신증후군으로 입원 15 일째 사망하였다.

\section{고 찰}

절제가 불가능한 담관암은 항암화학요법의 발전에도 불구 하고, 예후가 아주 불량하다. 고식적인 치료로 담관 폐쇄를 지연시키는 것이 예후를 향상시키고, 평균 생존 기간을 연장 시키는 것으로 보고되고 있어서 담관의 개존을 유지하는 것 에 치료의 초점이 맞추어지고 있다. ${ }^{3}$ 담관 폐쇄를 완화시키
는 방법으로는 경피적인 접근과 내시경적인 접근이 있으며, 가장 대표적인 방법은 내시경을 이용하여 담관 내에 스텐트 를 삽입하는 방법이다. 스텐트의 삽입은 자가 팽창형 금속 스텐트의 사용이 표준 치료로 받아들여지고 있으며 담관 개 존의 기간을 늘리는 것으로 보고되고 있다. ${ }^{4}$ 그러나 종양의 성장 및 이차 감염 등으로 스텐트 폐쇄가 일어나면 반복적인 시술이 필요한 제한점이 있다. ${ }^{1{ }^{1}}$ 최근 이를 보완하기 위해서 담관의 개존 기간을 늘리기 위한 치료로 국소적인 종양억제 방법인 광역동치료,12 및 고주파 열치료 ${ }^{1,11}$ 가 이용되고 있다. 악성 담관 폐쇄의 표준치료로 받아들여지고 있는 자가 팽창 형 금속 스텐트를 담관 내 고주파 열치료와 함께 적용한 경 우, 담관의 개존 기간과 생존율, 안정성에 대해 연구한 여러 문헌이 보고되고 있다. ${ }^{2,7}$ 한 연구에서는 스텐트의 삽입과 동 시에 담관 내 고주파 열치료를 적용하였을 때, 담관 개존이 평균 170일(금속스텐트 218일, 플라스틱 스텐트 115일)동안 유지되었으며, 시술 후 평균 생존 기간은 10.6 개월, 첫 진단 이후 평균 생존기간은 17.9 개월로 보고하여서 기존에 보고 되었던 스텐트 개존 및 생존 기간보다 우월한 것으로 보고하 였다. ${ }^{8}$ 또한 담관 내 고주파 열치료를 동시에 적용한 군과 스 텐트 단독으로 적용한 군과의 비교 연구에서는 평균 생존 기 간은 5.9 개월로 유의한 차이는 보이지 못하였으나, 담관 내 
고주파 열치료의 시행이 대조군에 비해 평균 생존 기간을 연 장시키는 독립 인자로 보고하였다. ${ }^{3}$

내시경적 역행성 담췌관조영술을 이용한 담관 내 고주파 열치료와 광역동치료의 차이를 비교한 연구에서는 두 군의 평균생존율은 9.6개월과 7.5개월로 고주파 열치료가 다소 높 은 결과를 보였지만, 통계적으로 유의한 차이는 없었으며, 중대한 합병증의 발생률 차이는 없었으나, 담관염이 고주파 열치료에서 더 자주 발생하는 것으로 보고하였다. ${ }^{9}$

고주파 열치료는 암 조직의 국소적인 응고괴사를 유도하 여 종양의 성장 및 상피세포증식을 지연시킴으로 담관의 개 존을 유지하는 방법으로, 효과적이며, 안전한 방법으로 알려 지고 있다. ${ }^{3,7,8,11}$ 또한 고주파 열치료는 광역동치료보다 시술 이 간단하며, 광과민감제 등을 사용하지 않는 점에서 시술이 간편하고, 비용이 저렴한 시술이며, 4-6주간 지속되는 광과민 현상을 포함한 광역동치료의 부작용이 없다는 장점이 있다. ${ }^{9}$

기존의 내시경적 역행성 담췌관조영술을 이용한 고주파 열치료는 투시조영을 통해 확인된 병변에 카테터를 삽입하 여 시술하는 방식이다. 협착부위에 열을 대칭적으로 적용하 는 방식으로 직접 병변을 시각화하지 못하는 단점이 있다. 여러 연구에서 고주파 열치료의 안정성을 보고하고 있으나, 정상 조직에 응고괴사를 유도하여 천공 뿐만 아니라 담관염, 췌장염, 담낭염, 혈액담즙증, 패혈증 등의 합병증을 발생시 킬 수 있다. ${ }^{1,2}$

최근 담관 질환의 진단과 치료에 세경 내시경을 이용한 직 접 경구하 담관 내시경이 이용되고 있다. Choi 등 ${ }^{12}$ 은 수술이 불가능한 간외 담관암 환자를 대상으로 직접 경구하 담관 내 시경을 이용한 광역동치료에 관한 연구를 시행하였으며, 9 명의 환자 중 7 명 $(77.8 \%)$ 이 성공적으로 시술을 마쳤으며, 피 부 발적 외의 시술 관련 합병증은 없는 것으로 보고하였다.

직접 경구 담관 내시경은 모자내시경(mother-baby scope) 방식의 담관 내시경에 비해 담관 내로의 삽입이 힘든 단점이 있으나 유도철선과 overtube의 사용으로 이를 극복하기 위 한 노력이 시도되고 있다. ${ }^{13}$ 내시경의 구경이 5-6 mm로 모자 방식의 담관 내시경에 비해 크지만 부속기구가 들어가는 워 킹 채널의 구경이 $2 \mathrm{~mm}$ 로 커서 스텐트나 고주파 열치료 등 의 시술에 필요한 부속기구의 사용에 유리하다. ${ }^{12,13}$ 또한 근 위부 담관암이나 총담관 결석과 같이 원위부 담관의 확장을 동반하는 질환에서 큰 구경의 내시경이 근위부 담관에 진입 하는 것은 타 질환에 비해 유리할 수 있다. 직접 경구 담관 내 시경하 고주파 열치료 시 직접 담관의 내부를 확인하면서 접
근이 가능하므로 병변의 위치와 형태를 직접 확인할 수 있으 며, 내시경 시야를 통해 원위부 폐쇄 병변 전면부의 확인이 가능하므로 폐쇄부위로의 카테터 삽입이 용이하다. 따라서 시술에 의한 출혈이나 천공 등을 줄일 수 있을 것으로 기대 되며 치료 도중이나 직후에 발생하는 합병증의 확인이 가능 하므로 대처에 유용할 것으로 보인다. 또한 총담관십이지장 문합술을 시행한 환자는 문합부가 넓어서 근위부 담관으로 의 접근이 용이하여, 쉽게 직접 경구 담관 내시경의 진입이 가능하다. ${ }^{14,15}$ 한 연구에서 총담관십이지장문합술을 받은 환 자에서 직접 경구 담관 내시경을 보조기구의 도움 없이 시행 하여 sump 증후군, 담관 협착 및 담관 결석의 진단과 치료가 가능하였던 증례를 보고하였다. ${ }^{15}$

본 증례에서는 총담관십이지장문합술을 시행 받은 담관암 환자에서 문합 부위를 통해서 직접 경구 담관 내시경하 담관 내 열치료를 적용하여서 스텐트 시술 없이 담관 개존을 보존 한 첫 번째 사례이다. 시술 후 환자가 간신증후군으로 사망 하기 전 3 개월간 담관 개존은 잘 유지되었다. 환자 사망으로 직접 경구 담관 내시경하 담관 내 고주파 열치료의 장기간의 추적관찰은 이루어지지 않았다는 제한점이 있었다. 향후 직 접 경구 담관 내시경하 담관 내 고주파 열치료의 안전성 및 효용성을 확인하기 위한 추가적인 연구가 필요할 것이다.

\section{요 약}

수술이 불가능한 담관암에서 담관 내 고주파 열치료는 악 성 담관 폐쇄를 호전시키는 실용적인 치료로 보고되고 있으 나, 내시경적 역행성 담췌관조영술을 이용한 고주파 열치료 는 투시조영을 통해 열을 적용하는 방법으로, 병변을 직접 시각화하지 못하는 단점이 있다. 반면에, 직접 경구 담관 내 시경하 담관 내 고주파 열치료는 담관 내 병변을 시각화함으 로써 카테터의 삽입 등에 용이하며 시술로 인한 합병증을 감 소시킬 수 있을 것으로 기대되고 있다. 본 증례에서는 총담 관십이지장문합술을 시행 받은 담관암 환자에서 직접 경구 담관 내시경하 담관 내 고주파 열치료를 적용하여서 스텐트 시술 없이 담관 개존을 보존한 첫 번째 사례로서 직접 경구 담관 내시경하 담관 내 고주파 열치료의 효용성을 문헌 고찰 과 함께 보고하는 바이다.

국문색인: 담관암, 담관 내 고주파 열치료, 직접 경구 담관 내시경 


\section{Conflicts of Interest}

No conflict among authors.

\section{REFERENCES}

1. Tal AO, Vermehren J, Friedrich-Rust M, et al. Intraductal endoscopic radiofrequency ablation for the treatment of hilar non-resectable malignant bile duct obstruction. World J Gastrointest Endosc 2014;6:1319.

2. Roque J, Ho SH, Reddy N, Goh KL. Endoscopic ablation therapy for biliopancreatic malignancies. Clin Endosc 2015;48:15-19.

3. Sharaiha RZ, Natov N, Glockenberg KS, Widmer J, Gaidhane M, Kahaleh $\mathrm{M}$. Comparison of metal stenting with radiofrequency ablation versus stenting alone for treating malignant biliary strictures: is there an added benefit? Dig Dis Sci 2014;59:3099-3102.

4. Soderlund C, Linder S. Covered metal versus plastic stents for malignant common bile duct stenosis: a prospective, randomized, controlled trial. Gastrointest Endosc 2006;63:986-995.

5. Kaassis M, Boyer J, Dumas R, et al. Plastic or metal stents for malignant stricture of the common bile duct? Results of a randomized prospective study. Gastrointest Endosc 2003;57:178-182.

6. Lee TY, Cheon YK, Shim CS, Cho YD. Photodynamic therapy prolongs metal stent patency in patients with unresectable hilar cholangiocarcinoma. World J Gastroenterol 2012;18:5589-5594.

7. Rustagi T, Jamidar PA. Intraductal radiofrequency ablation for management of malignant biliary obstruction. Dig Dis Sci 2014;59:2635-
2641.

8. Dolak W, Schreiber F, Schwaighofer H, et al. Endoscopic radiofrequency ablation for malignant biliary obstruction: a nationwide retrospective study of 84 consecutive applications. Surg Endosc 2014;28:854860.

9. Strand DS, Cosgrove ND, Patrie JT, et al. ERCP-directed radiofrequency ablation and photodynamic therapy are associated with comparable survival in the treatment of unresectable cholangiocarcinoma. Gastrointest Endosc 2014;80:794-804.

10. Parsi MA. Direct peroral cholangioscopy. World J Gastrointest Endosc 2014;6:1-5

11. Steel AW, Postgate AJ, Khorsandi S, et al. Endoscopically applied radiofrequency ablation appears to be safe in the treatment of malignant biliary obstruction. Gastrointest Endosc 2011;73:149-153.

12. Choi HJ, Moon JH, Ko BM, et al. Clinical feasibility of direct peroral cholangioscopy-guided photodynamic therapy for inoperable cholangiocarcinoma performed by using an ultra-slim upper endoscope (with videos). Gastrointest Endosc 2011;73:808-813.

13. Moon JH, Terheggen G, Choi HJ, Neuhaus H. Peroral cholangioscopy: diagnostic and therapeutic applications. Gastroenterology 2013;144:276-282.

14. Rosch W, Koch H. Peroral cholangioscopy in choledocho-duodenostomy--patients using the pediatric fiberscope. Endoscopy 1978;10:195198.

15. Choi HJ, Moon JH, Lee YN, et al. Direct insertion of an ultra-slim upper endoscope for cholangioscopy in patients undergoing choledochoduodenostomy. Dig Endosc 2015. [Epub ahead of print] 